\title{
The Brazilian surface freshwater framework in union-dominated rivers: challenges and prospects for water quality management
}

O enquadramento das águas doces superficiais brasileiras em rios de domínio da união: desafios e perspectivas para a gestão da qualidade hídrica

Vagner Alexandre Aparecido de Souza ${ }^{1}$ (D) , Denise Gallo Pizella² $(1)$

\section{A B S T RA C T}

The framing of surface water bodies is an instrument present in the National Water Resources Policy that aims to outline the goal of water quality to be maintained or achieved by water bodies, according to their predominant and intended uses by society. In view of the importance of the framework for water quality planning and the difficulties and possibilities for its implementation reported in the literature, this study aimed to identify them in the hydrographic basins of rivers in the Union's domain. In this sense, it was analyzed, in the most recent Plans of the nine basins with established committees, the aspects related to the framework; and, in order to diagnose the perspectives of the management bodies on the subject, electronic questionnaires were applied to the committees of the analyzed basins and to the National Water Agency. As a result, there was a lack of framing in accordance with current regulation, namely CONAMA Resolution no. 357/05, in all situations. The main problems identified for this were: lack of fluviometric data, distribution of water quality monitoring points in the basins in such a way as to make analysis difficult, diversity of legislation applicable to the framework in the States in which they are located, water pollution, and lack of articulation institutional relationship between water management bodies, States and municipalities. On the other hand, some potentialities for achieving the framework were verified, such as the implementation of the grant for the use of water resources in all situations, the existence of charges for the use of water resources in five of the nine basins in question, and a greater interaction between the water resources management bodies, States and municipalities in two of the analyzed basins.

Keywords: water management instruments; CONAMA Resolution no. 357/05; surface freshwater classification.

\section{RE S U M 0}

O enquadramento de corpos hídricos superficiais é um instrumento presente na Política Nacional de Recursos Hídricos que tem por objetivo delinear a meta de qualidade hídrica a ser mantida ou alcançada dos corpos hídricos, de acordo com seus usos preponderantes e pretendidos pela sociedade. Tendo em vista a importância do enquadramento para o planejamento da qualidade hídrica e as dificuldades e possibilidades para sua efetivação relatadas na literatura, este trabalho teve por objetivo identificá-las nas bacias hidrográficas dos rios de domínio da União. Nesse sentido, buscou-se analisar, nos planos mais recentes das nove bacias com Comitês instituídos, os aspectos afeitos ao enquadramento; e, no intuito de diagnosticar as perspectivas dos órgãos gestores sobre o assunto, foram aplicados questionários eletrônicos aos Comitês das bacias analisadas e à Agência Nacional de Águas. Como resultado, verificou-se a ausência de enquadramento de acordo com a normativa vigente, qual seja, a Resolução CONAMA no 357/05, em todas as situações. Os principais problemas identificados para tanto foram: carência de dados fluviométricos, distribuição de pontos de monitoramento da qualidade hídrica nas bacias de tal forma que dificultam as análises, diversidade de legislações aplicáveis ao enquadramento nos estados em que se encontram, poluição hídrica, e falta de articulação institucional entre os órgãos de gestão hídrica, os estados e os municípios. Em contrapartida, algumas potencialidades para a consecução do enquadramento foram verificadas, como a implantação da outorga de uso dos recursos hídricos em todas as situações, a existência de cobrança pelo uso de recursos hídricos em cinco das nove bacias em questão e uma maior interação entre os órgãos gestores de recursos hídricos, estados e municípios em duas das bacias analisadas.

Palavras-chave: instrumentos de gestão hídrica; Resolução CONAMA 357/05; classificação das águas doces superficiais.

\footnotetext{
${ }^{1}$ Master in Water Resources Management and Regulation, at Programa de Gestão e Regulação de Recursos Hídricos (PROFÁGUA), Engineering College, Universidade Estadual Paulista "Júlio de Mesquita Filho" (UNESP) - Ilha Solteira (SP), Brazil.

2Professor of PROFÁGUA at Department of Biology and Animal Science, Faculdade de Engenharia de Ilha Solteira, UNESP - Ilha Solteira (SP), Brazil. Departamento de Biologia e Zootecnia.

Correspondence address: Denise Gallo Pizella - Passeio Monção, 226 - Zona Norte - CEP: 15385-000 -Ilha Solteira (SP), Brazil.

E-mail: denise.gallo@unesp.br

Conflicts of interest: the authors declare that there are no conflicts of interest.

Funding: Coordenação de Aperfeiçoamento de Pessoal Nível Superior — Brasil (CAPES) — Funding code 001.

Received on: 02/17/2020. Accepted on: 05/01/2020.

https://doi.org/10.5327/Z2176-947820200707
} 


\section{Introduction}

The water bodies framework in classes is an instrument of the National Water Resources Policy, instituted by Law no. 9,433, of January 8,1997 , which is defined as the planning of water quality to be achieved or maintained according to the predominant and intended uses by society (BRASIL, 2005).

The water bodies subject to classification are all those of fresh, brackish and saline waters, with five classes for fresh water, six for brackish and six for saline (BRASIL, 2005). Freshwater, the object of this article, is classified according to quality grades, being more demanding in the Special Class, followed by Classes 1, 2, 3 and 4, as they are, respectively, becoming less restrictive in terms of quality.

According to Diniz et al. (2006), the creation of the National Environmental Council (CONAMA) Resolution no. 357, of March 17, 2005 , represents a major step forward to allow the progressive planning of river basins through the establishment of progressive and final goals consistent with institutional and technological performance, such as society's aspirations and availability of resources.

The framework has some methodological procedures for preparing its proposal, defined by the National Water Resources Council (CNRH) through Resolution no. 91, of November 5, 2008, which, in summary, provides stages of diagnosis, prognosis, proposals and programs for its implementation, that should include the participation of the local community, through public consultations, technical meetings, workshops, among others (BRASIL, 2008).

The framing proposal must be prepared by the Water Agencies and, in their absence, by the water resources management body, in conjunction with the environment body (ANA, 2013A), being the committee responsible for discussing, analyzing and forwarding the proposal to the respective Council (State or National), according to the water body domain, which should analyzed it, under possible adjustments and approved it in the form of Resolution (ANA, 2009).

It should be noted that water management occurs within the Union or the States scope, which, according to the Federal Constitution of 1988 , have the domain of the waters, in line with the scope defined in articles 20 and 26. In 1997, with the institution of the National Water Policy Resources and creation of the National Water Resources Management System, an institutional arrangement was formed that foresees the users and civil society participation in all federation instances (Union, States and municipalities), which Porto and Porto (2008) stand as a way of giving legitimacy to decisions and also being more efficient to guarantee the implementation of the decisions taken.

According to Brasil (2008), two aspects must be considered in the proposed framework, namely: surface and groundwater associated analysis and broad participation by the hydrographic basin community, through public consultations, technical statistics, workshops, among others. Once this process is completed, whose discussion takes place in the Hydrographic Basin Committee, the proposal must be submitted to the State Water Resources Councils (CERHs) or to the CNRH, de- pending of the water course domain, for appreciation, approval and deliberation (ANA, 2007).

It is important to highlight, in this context, the relationship between the instrument "framing of water bodies" and the Water Resources Plans, as they are, in their essence, planning instruments. Thus, it is necessary for these to be synergistic, since they are benchmarks for granting and charging for the use of water (ANA, 2013A).

Porto and Porto (2008) observed both in the framework of water resources and the Water Resource Plans a possibility of planning, embodied in participatory processes that involve both civil society and economic agents with individuals (public and private) interests.

The framework, according to Yassuda (1993), demands institutional mechanisms capable of respecting the political, social, economic and environmental consequences for local users and for the population affected by it. In this context, the author warns that it is difficult to reach a balanced decision in the absence of a reliable information system, and, therefore, it is assumed that the development of this instrument in river basins is essential both for the realization of the framework and for monitoring over the horizon of the idealized planning.

According to Diniz et al. (2006), Brandão et al. (2006), ANA (2007), Pizella and Souza (2007), Porto and Porto (2008), Braga et al. (2008), Corrêa et al. (2013), Silva (2017) and Foleto (2018), some of the obstacles to make the framework effective are: absence of Basin Plans and Plans without consolidation, which do not perform actions that corroborate for the framework to be achieved; deficiencies in social participation and methods used; difficulties in the institutional articulation between the Basin Committees and the municipalities; lack of a comprehensive water monitoring and inspection system, which makes it impossible to assess whether the framework is being effective; inexistence of charges for the use of water resources in several basins, making it difficult to allocate budgets to management and grant systems that disregard the reality of water quality.

In this sense, researches are needed that addresses the problems related to the implementation of this fundamental instrument for the progressive improvement of water quality in a country, in order to consider the main existing technical, budgetary and institutional limitations and ways of overcoming them. Therefore, this work aims to identify difficulties and potentialities related to the framing of river basins in the Union domain, pointed to Basin Plans, pointed out in the Basin Plans, documents that guide the instrument under study, and in the perspectives of water resources managers, who are aware of the management challenges in the basins, in order to point out improvements for their effectiveness.

\section{Metodology}

The Research had a qualitative and quantitative approach as to its nature, explanatory, in terms of its objectives and survey, as to its procedures, according to Gil (2002). It was carried out as follows. 
First, an analysis was made of the most recent Basin Plans for rivers in the Union domain with Hydrographic Basin Committees in operation, namely: Piracicaba River, Capivari River and Jundiaí River; Paranapanema River; São Francisco River; Paranaíba River; Paraíba do Sul River; Grande River; Piancó-Piranhas-Açu River; Verde Grande River and Doce River, which their Basins are represented in Figure 1.

In each Hydrographic Basin Plan, the following aspects were identified:

- Committee creation data;

- General characteristics of the basin: drainage area, total population and number of municipalities;

- Quality of surface freshwater, in terms of the main factors that affect it;

- Whether or not there is a classification of surface freshwater and the main problems identified for achieving it.

Also, in order to identify the main problems and potentialities for the instrument from the point of view of the water resources management bodies (Committees and the National Water Agency), semi-structured electronic questionnaires were developed, on a digital platform, with multiple choice questions. In the presentation of the study, the participants only answer questions if they agree with the Informed Consent Term (ICF), for ethical reasons in the research.

The questionnaires were sent to the nine Interstate River Basin Committees in the country, which questions are found in Appendix 1 of the article. For each committee, a representative of a Technical Chamber qualified with the study and implementation of any of the instruments of the National Water Resources Policy was selected to answer the questions, that is, to the granting, planning, charging or framework sector of the water resources. All the committees answered the questionnaire, with the exception of the Piancó-Piranhas-Açu River, Verde Grande River and Doce River committees.

In view of the knowledge about the situation of rivers in the Union's domain by the National Water Agency, questionnaires related to each of the nine hydrographic basins under analysis were sent to this body. The respondent was a specialist who works in the area of the water resources framing, with whom the researchers had a previous contact, in order to verify its knowledge about the Water Resources Plans under analysis and the framework instrument.

The questions addressed to the managers dealt with the factors that affect the water quality in the Basins under study; the presence or not of framing of surface freshwaters and the factors that hinder or enhance the implementation of the instrument, such as the existing State legislation and its current status with CONAMA Resolution no. 357/05; the existence or not of charging and granting for the use of water resources; monitoring of water quality and fluviometric quantity and its proper spatialization, in addition to the institutional difficulties and potential of articulation between the proposals of the committees and the land use policies of the municipalities. For all questions, that was of multiple choice, it was left an opportunity for respondents to external their views on the subject addressed.

The analysis consisted of identifying the aspects related to the framework instrument present in the Basin Plans, including the questionnaires responded to the managers, making comparisons between the two contents.

\section{Results}

Hydrographic Basins of the Piracicaba, Capivari and Jundiaí Rivers

The Committee of the Hydrographic Basins of the Piracicaba, Capivari and Jundiaí Rivers (Federal PCJ) was established by the Presidential Decree of May 20, 2002. These basins have a drainage area of $15,303 \mathrm{~km}^{2}$, distributed between the States of São Paulo (92.45\%) and Minas Gerais (7.55\%), covering the total and/or partially of 76 municipalities ( 5 from Minas Gerais and 71 from São Paulo), with 5.8 million inhabitants (PROFILL; RHAMA, 2018a).

The water quality monitoring network of the PCJ Basins comprises nine stations of the Minas Gerais Institute of Water Management (IGAM) and 94 stations of the Companhia Ambiental Paulista (CETESB), with a density of 6.70 points/1,000 km² (PROFILL; RHAMA, 2018b), higher than the target established by the National Water Quality Monitoring Network, whose minimum predicted is 1 point $/ 1,000 \mathrm{~km}^{2}$ (ANA, 2012).

In this way, this aspect does not give a weakness to the framework, since the existing stations subsidize the framework and are guiding its review. For ANA, in the response to the questionnaire, the quantity, as well as the distribution of quality monitoring points in the basins, is satisfactory. On the other hand, the perception of the PCJ Committees indicate that the frequency of surface water quality testing practiced by CETESB and IGAM are critical factors for the classification, as it would be desirable to be closer to the flow rate monitoring network.

Regarding fluviometric monitoring, the PCJ Committee considered its spatialization inadequate, which makes hydrological studies difficult, mainly for the Capivari and Jundiaí Rivers.

As for water quality, both the Committee and the PCJ addressed that its commitment is related to the uses of water for the dilution of sanitary sewage (in natura and treated), the receipt of rainwater in the urban environment and the release of industrial effluents.

The granting records in rivers of federal dominance correspond to 23 surface abstractions and 42 for the discharge of effluents and application in soil (PROFILL; RHAMA, 2018b). According to ANA, in the granting process, one of the analysis criteria is the quality of the water course, whose parameters are only BOD 5,20 and total phosphorus. The charge for the use of water resources was also implemented in the PCJ Basins. However, ANA is unaware if the financial resources are adequate to monitor and update the framework, while the PCJ committee reports that they are that are not enough for this purpose.

Regarding the normative and legal aspects related to the water classification in the PCJ basins, it was observed in consultation with ANA, 


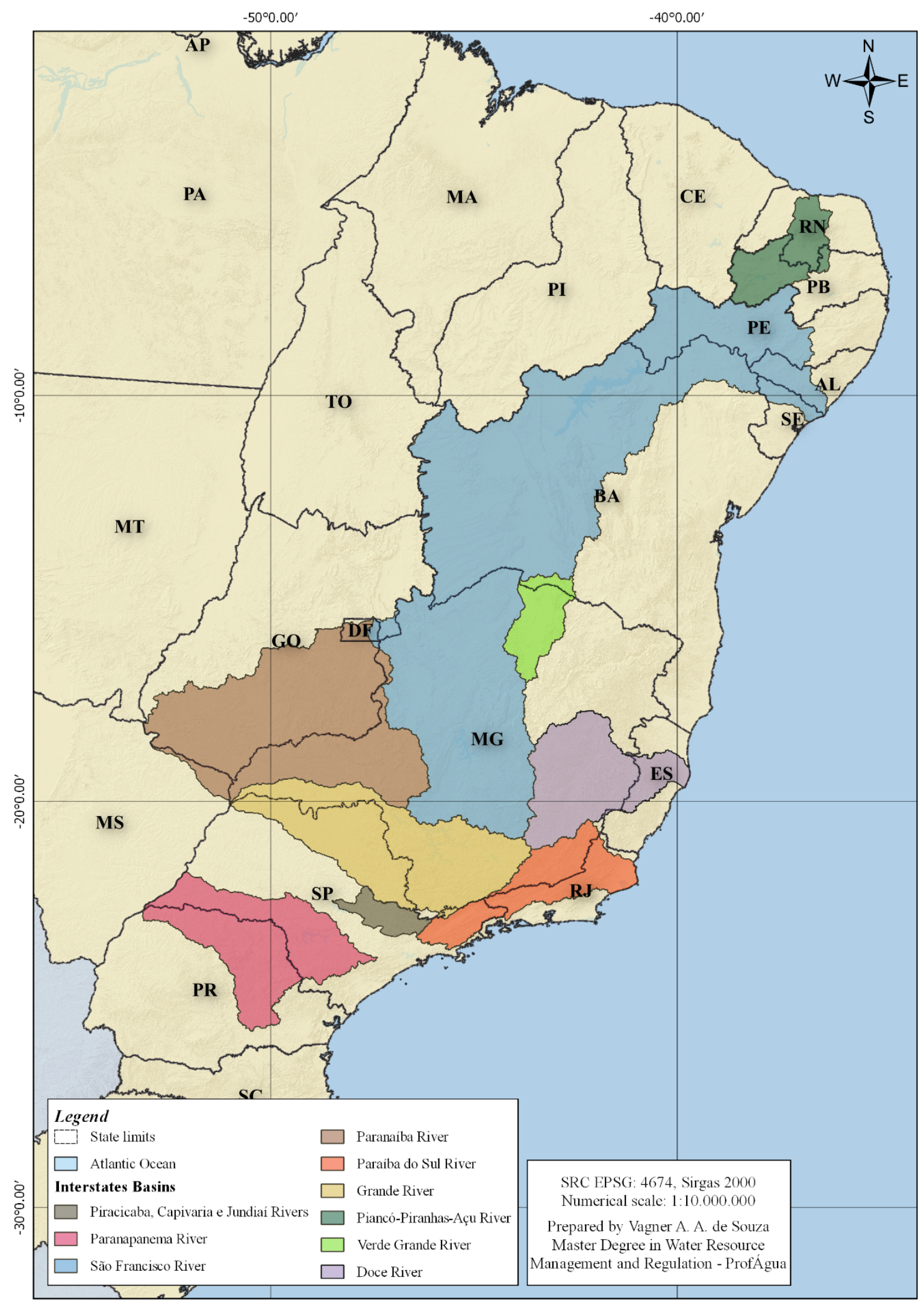

Figure 1 - Study area: Interstates Basins with Basin Committees installed. 
through the questionnaire, that the classification is formalized only by State Decree in São Paulo. However, it is in discussion and review within the PCJ committee.

Regarding the institutional articulation for the elaboration and implementation of the framework between ANA, the Basin Committees, the States and the municipalities, ANA considered its existence in an initial phase. On the other hand, the committee assessed there is an obvious limitation in this regard, with no aligning goals between the Municipal Basic Sanitation Plans and the Basin Plans, as an example.

\section{Hydrographic Basin of the Paranapanema River}

The Paranapanema River Basin Committee was established through CNRH Resolution no. 120, of December 16, 2010. The basin has an area of $106,500 \mathrm{~km}^{2}$, distributed between the States of São Paulo (48.60\%) and Paraná (51.40\%), draining water from 247 municipalities (115 from São Paulo and 132 from Paraná), with a population of 4,680,725 inhabitants (ANA, 2016B).

In relation to the fluviometric network, according to the consultation with the Basin Committee, a distribution of the fluviometric monitoring points is unsatisfactory, requiring an expansion.

Regarding water quality monitoring, there are 40 stations, 17 belonging to CETESB, in the São Paulo portion and 23 in the Paraná portion (Águas Paraná), as well as 37 stations of the Duke Energy monitoring system (used for self-monitoring of concessionaires that operate reservoirs of hydroelectric plants located on the Paranapanema River) (ANA, 2016B).

Concerning the density of monitoring points of 1 point $/ 1,000$ $\mathrm{km}^{2}$ recommended as a goal by the National Water Quality Monitoring Network (ANA, 2012), it can be note that the density in the basin is lower than recommended.

The main aspects highlighted both in the Basin Plan and in the consultation with the Committee, which compromise the quality of surface water, refer to the uses for dilution of sanitary sewage and urban areas. However, ANA (2016B) highlights that the agricultural sector can be a relevant source of nutrient input to water courses, as it is widely observed within the limits of the basin.

As for the normative and legal aspects involved in the framing of water courses, ANA, in the answer to the questionnaire, mentioned that its formalization took place from meetings of the CEEIPEMA (Executive Committee for Integrated Studies of the Paranapanema River Basin) of 1980. In the stretches of the São Paulo side, it was used the State Decree (SP) no. 10.755/1977, and in the Paranás stretches, the SUREHMA/PR no. 6/1991. The Resolution CERH/PR no. 100/2016 framed the surface water bodies of the Tibagi River. In this sense, the methodology adopted for the framing of water bodies was predominantly used in Ordinances and Resolutions prior to CONAMA Resolution no. 357/2005.

The granting of rights to use water resources in rivers belonging to the Union is implemented in the Basin, with the quality of the water course used for analysis, specifically to the parameters BOD5,20 and total phosphorus, according to ANA reports. Charging for the use of water resources has not been implemented in the basin. In this sense, the Basin Committee relate that the implementation of charging for the use of water resources would be a factor that would corroborate for the elaboration of studies for the framing of superficial water courses in the Basin.

Concerning the articulation between the institutions involved in water management, both ANA and the committee considered that it is necessary, but incipient.

\section{Hydrographic Basin of the São Francisco River}

The São Francisco River Basin Committee (CBHSF) was established by the Presidential Decree of June 5, 2001. The basin has an area of $639,219 \mathrm{~km}^{2}$, covering 505 municipalities in six States of the Federation, namely: Minas Gerais, Goiás, Bahia, Pernambuco, Alagoas and Sergipe, in addition to the Federal District (CBHSF, 2016).

According to consultation with the committee, a number of points for fluviometric monitoring is considered unsatisfactory, what makes it difficult to classify water courses.

The water quality monitoring network encompasses 362 stations, including a monitoring network of ANA and the States of Minas Gerais and Bahia. Regarding the density of monitoring points of 1 point $/ 1,000 \mathrm{~km}^{2}$ recommended as a goal by the National Water Quality Monitoring Network (ANA, 2012), the basin density is of 0.56 , lower than recommended.

The main aspects highlighted in the Basin Plan that compromise the quality of surface water in the basin refer to the uses of dilution of sanitary sewage, urbanization processes, the inadequate disposal of waste, mining and agricultural activities (CBHSF, 2016). These aspects are evidenced by both ANA and the committee, being the first highlight the lack of sanitation in the basin.

In consultation with ANA, the framework for water courses was formalized through various regulations, such as: IBAMA Ordinance no. 715/1989 for rivers belonging to the Union; CRH/DF Resolution no. 02/2014 for rivers in DF domains; COPAM Normative Resolution no. 14/1995 for stretches of affluent basins on the Paraopeba rivers; COPAM Normative Resolution no. 28/1998 and Normative Resolution COPAM no. 20/1997 in Pará, in addition to CONERH/BA Resolution no. 112/2018 for the bodies of water in the Salitre River Basin, in Bahia. In addition, CBHSF (2016) mentions the framing of the Piauí River (Alagoas) by Decree no. 3,766/1978.

In the Water Resources Plan for the horizon from 2004 to 2013, a proposal was made to reframe the water bodies. In summary, this proposal follows the CONAMA Resolution no. 357/05, except in the Middle São Francisco, where the proposal is more demanding than the provisions of this Resolution. The committee commented that such a proposal does not reflect the reality of the preferred uses in the Basin, requiring the updating of the framework and an effective Plan that affects the better management of surface. 
In the São Francisco River basin, it can be seen that the grant of the rights to use water resources have been implemented and the water quality is one of the requirements for its concession, the quality parameters being only BOD 5,20 and total phosphorus, according to ANA's report. Charging for the use of water resources was also implemented in the Basin. ANA judged that the financial resources from charging are accessible for the preparation of the proposed framework and its monitoring.

Regarding the institutional articulation between ANA, the committee, the States and the municipalities on the discussion of the framework, ANA explains that it finds in the initial phase. On the other hand, the perception of the Basin Committee was diverse, indicating its inexistence and that the strengthening of this depends on actions by the Public Power.

\section{Hydrographic Basin of the Paranaíba River}

The Paranaíba River Basin Committee was established by the Presidential Decree of July 16, 2002, being installed only on July 10,2018 . The basin has an area of 222,600 km², covering $197 \mathrm{mu}-$ nicipalities, in three States: Goiás, Mato Grosso do Sul and Minas Gerais, in addition to the Federal District.

According to the committee, the number of points for fluviometric monitoring is unsatisfactory, what brings the difficulty of the water courses frameworking.

Regarding the characterization of the surface water quality monitoring network, the Basin Plan highlights that sampling points from the hydroelectric sector, public supply concessionaires and State management agencies were used. However, the quantification of the existing network has not been presented. One of the proposals of the Basin Plan aims to expand the surface water quality monitoring network, noting that the existing network is insufficient for the dimensions of the basin, which requires standardization of the analyzed parameters and the sampling frequency (ANA, 2013b).

The main aspects highlighted in the Basin Plan that compromise the quality of surface water refer to uses for agriculture, the urban areas and dilution of domestic and industrial effluents (ANA, 2013b). These aspects were also highlighted by ANA and the committee, in the questionnaires. However, ANA has little information on interference from diffuse polluting sources, such as livestock and agriculture.

In consultation with ANA, it was observed that the framework of water courses was approved by the committee according to the current rule, requiring approval by the $\mathrm{CNRH}$, whose adjustment requests will be made from 2019.

In this basin, it was observed that the grant to the rights to use water resources has been implemented and that one of the analysis criteria is water quality, whose patterns used are only DBO5,20 and total phosphorus. The charge for the use of water resources was also implemented in the basin, from the approval of Resolution CNRH no. 185/2016 (ANA, 2013b).
Concerning the institutional articulation between the water resources management bodies, States and municipalities, ANA considers that there is on an initial phase a different perspective from the committee, which points to its inexistence.

\section{Hydrographic Basin of the Paraíba do Sul River}

The Paraíba do Sul River Basin Integration Committee (CEIVAP) was established by Federal Decree no. 1,842, of March 22,1996 . The hydrographic basin has an area of $56,584 \mathrm{~km}^{2}$, distributed between the States of São Paulo (22.73\%), Rio de Janeiro (43.51\%) and Minas Gerais (33.76\%), comprising 184 municipalities, 39 from São Paulo, 59 from Rio de Janeiro and 88 from Minas Gerais (COHIDRO, 2014).

The number of fluviometric monitoring points are considered satisfactory, according to the Basin Committee.

The network for monitoring water quality encompasses a total of 115 stations. Regarding the density of monitoring points of 1 point $/ 1,000 \mathrm{~km}^{2}$ recommended by ANA (2012), the basin presents 1.87 points/1,000 $\mathrm{km}^{2}$ (PROFILL, 2018), being considered satisfactory. On the other hand, the committee's perception indicates that the surface water quality monitoring network and the distribution of its points are unsatisfactory.

The main aspects highlighted both in the Basin Plan, as well as in consultation with the committee and ANA, that compromise the quality of surface water, refer to the uses for dilution of sanitary sewage, industry, agriculture, livestock and urban areas. However, ANA reports the weights for each of these agents should be the object of study in the review/adequacy of the framework.

Regarding the normative and legal aspects related to the framing of water courses, ANA shows that, in rivers belonging to the Union, the currently framework was defined by Ordinance Minter no. 86 of 1981; in the State of São Paulo, by State Decree no. 10.755 of 1977; and in the State of Minas Gerais, on the Paraibuna River and its tributary, by the COPAM Resolution no. 16 of 1996, all of which need to be reframed according to the current rule.

Still, ANA includes that the committee is preparing a review of the Water Resources Plan and has been discussing the possibility of preparing in sequence the complementary studies for review/adjustment of the framework.

The granting of rights to use water resources was carried out, and the committee points out that this instrument needs improvement, in order to standardize its criteria considering the natural area instead of the administrative area. The water quality parameters considered are BOD 5,20 and total phosphorus. There is the charge for the use of water resources and the committee pointed out that the resources are sufficient for monitoring the framework, but not for its implementation.

Concerning the institutional articulation between ANA, the committee, the States and the municipalities in the discussion of the 
framework, ANA explains that it exists in part, but without mentioning how it is being carried out. The committee already lists its presence, highlighting that the framework is a joint construction and that there must be an agreement on the quality standards adopted as a goal and the ways to achieve it.

\section{Hydrographic Basin of the Grande River}

The Grande River Basin Committee was established through Resolution CNRH no. 11, of April 13, 2010. The basin has 143,255 $\mathrm{km}^{2}$ and its waters are distributed between the States of São Paulo (40\%) and Minas Gerais (60\%), with Grande River being the main water course, with an extension of $1,286 \mathrm{~km}$, which drains water from 393 municipalities, 214 from Minas Gerais and 179 from São Paulo (ANA; CBH GRANDE, 2017).

The water quality monitoring network comprises 148 stations. In relation to the density of monitoring points of 1 point $/ 1,000 \mathrm{~km}^{2}$ recommended as a goal by the National Water Quality Monitoring Network (ANA, 2012), the density in basin is 1.03 point $/ 1,000 \mathrm{~km}^{2}$ (ANA; CBH GRANDE, 2017), what can be considered adequate. However, ANA considers the surface water quality monitoring network and the distribution of sampling points unsatisfactory, especially in Minas Gerais portion of the basin.

The main causes pointed out in the Basin Plan for the depreciation of water quality in the Class 4 stretches refer to the discharge of urban domestic sewage and some stretches associated with the discharge of industrial effluents (ANA; CBH GRANDE, 2017). The main aspects highlighted in the consultation with ANA that compromise the quality of surface water refer to the uses for dilution of sewage, industry, agriculture, livestock and urban areas.

ANA pointed out that there was no formalization of the water courses framework, considering the stretches of the Union domain, but in the stretches located in the State of São Paulo, which follow State Decree (SP) no. 10.755, of 1977. In compliance with the Plan, it was noted that there are only guidelines for the implementation of the reframing, mainly regarding the carrying out of complementary studies to comply with Resolution CNRH no. 91/2008, included in the Implementation Program for the Framework/Reframing of the Basin Water Bodies Program, with investment goals between 2018 and 2030 (ANA; CBH GRANDE, 2017).

The granting of rights to use water resources was instituted in the basin, and the water quality values considered were BOD5,20 and total phosphorus. According to information available in the $\mathrm{Ba}$ sin Plan, there is no charge for the use of water resources in rivers belonging to the Union. On the State level, São Paulo has the charge in place (ANA; CBH GRANDE, 2017).

Concerning the institutional articulation between ANA, $\mathrm{CBH}$ GRANDE, the States and municipalities in discussion of the framework, ANA lists its presence in an initial phase. The Basin Committee did not respond to the questionnaire.

\section{Hydrographic Basin of the Piancó-Piranhas-Açu River}

The Piancó-Piranhas-Açu River Basin Committee was established through the Presidential Decree of November 29, 2006 (CBH DO RIO PIANCÓ-PIRANHAS-AÇU, 2019). The basin has an area of $43,683 \mathrm{~km}^{2}$, distributed between the States of Paraíba (60\%) and Rio Grande do Norte (40\%), with the Piancó River (rising until its confluence with the Piranhas River) and the Piranhas River (from confluence with the Piancó River to the Armando Ribeiro Gonçalves reservoir), the main water courses, which drain water from 147 municipalities, 100 belonging to the State of Paraíba and 47 to Rio Grande do Norte (ANA, 2018).

According to ANA, the distribution of the fluviometric monitoring points is considered unsatisfactory in the basin.

The water quality monitoring network of the Piancó-Piranhas-Açu River Basin comprises 91 stations, 69 located in dams and 22 in rivers in the basin (ANA, 2018).

In relation to the density of monitoring points of 1 point/1,000 $\mathrm{km}^{2}$ recommended as a goal by the National Water Quality Monitoring Network (ANA, 2012), the density of the basin is 2.08 points/1,000 km² (ANA, 2018). However, the Basin Plan shows a lack of representativeness of the series of quality data, providing for an operation of an additional 59 monitoring points (ANA, 2018). In this sense, with a view to monitoring water quality as a limitation for the formalization of the framework, this aspect gives the instrument a weakness. ANA's perception of monitoring the quality of surface water in the basin, as well as the distribution of its points, is considered unsatisfactory.

The main aspects evidenced both in the Basin Plan, as well as in the consultation with ANA, that compromise the quality of surface water, refer to the uses for dilution of sanitary sewage, agriculture and livestock. However, ANA points out that, as monitoring is deficient, it is very difficult to accurately establish the share of pollutant contributions from each sector.

Also, through consultation with ANA, it is possible to observe that there is no framework of rivers belonging to the Union domain in the basin, with their water courses automatically included in Class 2, according to Brazil (2005).

The water use rights grant was instituted and considers as water quality parameters only DBO5,20 and total phosphorus. The charge has not been implemented.

Regarding the institutional articulation between ANA, CBH GRANDE, the States and municipalities in discussion of the framework, ANA lists its presence in an initial phase. The Basin Committee did not respond to the questionnaire.

\section{Hydrographic Basin of the Verde Grande River}

The Verde Grande River Basin Committee was established by the Presidential Decree of December 3, 2003. The basin has an area of $31,410 \mathrm{~km}^{2}$, distributed between the States of Bahia (13\%) and 
Minas Gerais (87\%), being Verde Grande River the main water course, which has waters from 35 municipalities, 8 belonging to the State of Bahia and 27 to Minas Gerais (ANA, 2016a).

The water quality monitoring network comprises 16 stations. In relation to the density of monitoring points of 1 point $/ 1,000 \mathrm{~km}^{2}$ recommended as a goal by the National Water Quality Monitoring Network (ANA, 2012), the basin has a density of 0.60 point $/ 1,000$ $\mathrm{km}^{2}$ (ANA, 2016a), insufficient, therefore. The Basin Plan considers the need for expansion and better distribution of these points, in agreement with ANA.

The main aspects highlighted in the Basin Plan, as well as in ANA, which compromise the quality of surface water, refer to the uses for diluting sanitary sewage, agriculture and livestock.

According to ANA, the framework for water courses in the Union domain was formalized based on the MINTER/IBAMA Ordinance no. 715 , of September 20,1989. In the Basin Plan, it was observed that the framework was included only in the Investment Programs, in view of the existing surface water quality problems and because the current framework is based on instruments prior to Brazil (2005).

A water use rights grant was instituted and considers as water quality parameters only DBO5,20 and total phosphorus. The charge has not been implemented.

Regarding the institutional articulation between ANA, $\mathrm{CBH}$ GRANDE, the States and municipalities in discussion of the framework, ANA lists its presence in an initial phase. The Basin Committee did not respond to the questionnaire.

\section{Hydrographic Basin of the Doce River}

The Doce River Basin Committee was established by the Presidential Decree of January 25, 2002. The basin has an area of 86,715 $\mathrm{km}^{2}$, distributed between the States of Minas Gerais (86\%) and Espírito Santo (14\%), being Doce River its main water course, covering $850 \mathrm{~km}$ from its source in the Mantiqueira and Espinhaço Mountains (Minas Gerais) to the Atlantic Ocean and draining waters from 229 municipalities, 203 of which belong to Minas Gerais and 26 to Espírito Santo (ANA, 2013c).

In relation to the quantity of fluviometric monitoring points in the Doce River Basin in its sufficiency or not for the framing of surface water bodies, ANA has shown to be unaware of the matter.

The water quality monitoring network of the Doce River Hydrographic Basin comprises 41 stations from the Minas Gerais Water Management Institute (IGAM) and the State Institute of Environment and Water Resources (IEMA) (ECOPLAN, 2010). Regarding the density of monitoring points of 1 point $/ 1,000 \mathrm{~km}^{2}$ recommended as a goal by the National Water Quality Monitoring Network (ANA, 2012), the density in the Basin is 0.47 point $/ 1000$ $\mathrm{km}^{2}$ (ECOPLAN, 2010), which can be considered insufficient. For ANA, the quantity, as well as the distribution of quality monitoring points in the basins, are considered satisfactory. However, it points out that there may be some monitoring deficiencies in Doce River basins affluents.

The main aspects highlighted in the Basin Plan, as well as in ANA, which compromise the quality of surface water in basin, refer to industrial uses, dilution of sanitary sewage, agriculture, livestock, urban areas and mining activity.

Concerning the normative and legal aspects involved on the theme of framing water courses in the domain of the Union, ANA pointed to its inexistence, and its waters are considered automatically in Class 2, as recommended by Brazil (2005).

In the Basin Plan, the framing of surface waters was considered only in the Basin Management Guidelines, from the outline of desirable quality goals for the water bodies considered, once the examination of most of the data and the necessary information was insufficient to prepare a proposal for a framework compatible with the relevant environmental standards (ECOPLAN, 2010).

In this way, the Plan defines an arrangement of guidelines for the development of this instrument, considering, in addition to legal, technical and operational aspects, the local specificities of the Basin (ECOPLAN, 2010).

The granting of rights to use water resources in rivers in the domain of the Union is present and considers as water quality parameters only DBO 5,20 and total phosphorus.

The charging for the use of water resources was implemented, with sufficient raising of financial resources for the application of the water courses adjustment proposal and/or monitoring in the cases of rivers in which they have already been implemented, once it is foreseen the beginning of the application of the proposal above in early 2019, together with the revision of the Basin Plan, according to ANA reports.

According to ANA, there is a beginning of institutional articulation between the committee, States and municipalities in the basin, with no explanation of its structure. The Basin Committee did not respond to the questionnaire.

\section{Discussion}

In the responses to the questionnaires, ANA assessed the quality of surface water in the analyzed basins as regular, in general, except in the Piancó-Piranhas-Açu Rivers basin, where poor quality predominates. The committees of the hydrographic basins of the Paranapanema and São Francisco rivers presented more optimistic points of view in relation to that evidenced in their Basin Plans and by ANA, characterizing the quality of the surface waters in their basins as adequate to the quality standards of the current classes of water resources. It is important to highlight that there is better detail regarding the water quality present in the Basin Plans than in the narratives presented by ANA and committees.

In general, quality problems are related to sources of pollution, such as sewage, occasional industrial launches and diffuse loads of agricultural activities and urban drainage. 
According to Diniz et al. (2006) and Brandão et al. (2006), the lack of supervision of these economic activities is a factor that leads water bodies already classified to remain in disagreement with a designated quality class, making it difficult for basin managers to propose a reframing of surface water bodies.

In the Basin Plans analyzed, 55\% have a surface water quality monitoring network density of less than 1 point $/ 1,000 \mathrm{~km}^{2}$, as recommended by ANA (2012). ANA reported that only the surface water quality monitoring network in the PCJ Basins is satisfactory, with the others being regular, with the exception of the Grande, Piancó-Piranhas-Açu and Verde Grande rivers, which are considered unsatisfactory.

On the other hand, according to the Basin Committee that participated in the research, there is a need to expand the monitoring network and/or even improve the distribution of existing points. However, according with the Paranaíba River Basin Committee, it is necessary to improve the understanding of the committees with this respect, such as the model of bulletins generated by the management agencies.

According to Cunha et al. (2013), problems related to monitoring water quality make it difficult to verify compliance with the quality standards assigned to water courses. This factor is corroborated by Foleto (2018), Diniz et al. (2006) and Brandão et al. (2006), which relate the difficulties of water resource management with the deficiency of water quality monitoring, being that the points must be expanded, best distributed in space and the measurements standardized in terms of the quality parameters used.

In the Basin Plans and in the answers to the questionnaires, it was found that, in general, the quantity and distribution of fluviometric stations in the basins are in deficit, with the need to expand historical series to improve hydrological analysis. In addition, there was a need for such points to be closer to those for monitoring water quality, in order to improve the understanding of water courses and, therefore, the reframing proposal.

Regarding to the framework of watercourses, in most basins, there are federal normative prior to the PNRH, as well as different State norms prevail, without uniform rules in the same hydrographic basin.

With these factors in perspective, the Basin Committees considered that the most water courses in the Union domain are not framed, being its waters automatically in class 2 , independently of the classes that are in force in the States. In fact, in spite of the Basin Plans present guidelines for the revision of the framework, until its proposal is made in accordance with the current rules, the water courses under analysis are non-compliant.

In all cases studied, therefore, it is necessary the review of the framework, so that water courses are classified based on current rules, in terms of requirements for defining water quality standards and their processing in the appropriate institutional instances, as recommended by CNRH Resolution no. 91/2008. In this way, it is important to highlight that the basins of the PCJ and Paraíba do Sul rivers are in the pro- cess of updating the framing of superficial water bodies in the molds that determine the legal provisions currently in force.

As for the strengths for a reframing proposal, it was noted in the Basin Plans of the PCJ and Paraíba do Sul, a factor that may have acted as a facilitating agent, that is, the presence of a Delegation Basin Agencies, which ones, even if they have not elaborated the Plans and the framing proposals, has a specialized technical staff that may have helped the environmental consultancy.

A necessary factor for the creation and strengthening of Basin Agencies refers to the implementation of charging for the use of water resources, an aspect evidenced by the PCJ, Paraíba do Sul and Paranaiba committees, which considers the resources from charging in their areas of coverage sufficient to enable the elaboration of framework studies.

In this sense, stands out that the Paranapanema River Committee considers that charging, not yet instituted in the basin, is a factor that corroborates the preparation of the water framework studies. In fact, charging for the use of water resources makes it possible to collect financial resources that can be used to improve knowledge of the characteristics of hydrographic basins and in clean-up programs that help with waters framework, according to Brites (2010).

An important aspect of the framework is its relationship with the instrument granted for the rights to use water resources, especially for effluent releases for dilution in water courses, because, when considered in the mass balance for verification in the mixing zone, it will provide the regulator agent the knowledge of the absorption capacity without violating the limits of the current framework.

In this theme, the Basin Plans analyzed do not provide information about the synergy between charging, granting and water framework instruments, essential to combine water quality and quantity, considering the intended uses.

However, through the questionnaire submitted to ANA and the basin committees, it was possible to identify that granting, instituted in all the Basins analyzed, consider as a criterion for its concession the maintenance of the water body class, specifically for DBO5,20 and total phosphorus. Nevertheless, it should be noted that only two water quality parameters are an inadequate quantity to determine the quality of a water course, mainly in view of the water classification system in CONAMA Resolution no. 357/05, which quality standards refer to a set of more complex physical, chemical and biological parameters.

The agents interviewed identified a deficiency in institutional articulation between the environmental and water resources management bodies, as well as the vertical articulation between municipalities, States and the Union. According to ANA, an arrangement in an initial stage of development occurs in the Paraíba do Rio Sul and Doce basins, without, however, presented the adopted format.

In fact, according to Pizella (2015) and Oliveira-Andreoli et al. (2019), the municipalities are responsible for ordering of land uses, delimiting the areas of urban expansion and the establishment of different 
types of human activities in urban and rural areas, with their functions and limits, given by social, economic and environmental issues. The municipal policies generated, therefore, positive and negative socioenvironmental impacts with different magnitudes on water resources, in terms of their quality and quantity. However, the administrative limits of the municipalities do not coincide with the drainage area of water courses present in the hydrographic basins, whose planning takes place on a regional basis, through the Hydrographic Basin Plans, under the responsibility of the Basin Committees. In order to reduce the negative effects on water resources and the Basin Plans achieve its improvement goals on them, the authors propose that both the committees and the municipalities promote dialogue mechanisms and participation in both the public politics, that is, in plans related to land use, such as Environmental Zoning and Municipal Master Plans and Water Resources, represented by Basin Plans.

At this moment, the water resource managers responding to the questionnaires indicated that the Municipal Basic Sanitation Plans, executed by the municipalities, can align their sewage collection and treatment goals with the Basin Plans, as an example. To this end, the committees can create communication strategies and convincing the municipalities to enhance its presence in the plenary discussions of these entities. In addition, the greater involvement of diverse social actors, such as users and social groups of society present in the basins, is considered essential for the objectives outlined in the plans related to water resources are transparent, known, jointly elaborated with the residing population in the basins and, as a consequence, effective, according to Rodorff et al. (2015), consolidating the principle of participatory management present in the National Water Resources Policy.

\section{Conclusion}

This article identified the challenges to the framing of surface freshwaters in the hydrographic basins of the Union domain with constituted Basin Committees, in order to present the main conditions that affect the implementation/monitoring of this instrument, based on the analysis of the Basin Plans and interviews with Hydrographic Basin Committees, as well as with ANA. Thus, the main problems observed were:

- deficiencies in the inspection of polluting sources in all the analyzed basins, evidenced by the worse quality of the water courses due to occasional releases of sanitary sewage and of diffuse loads from agricultural activities and urban areas;

- problems related to water quality monitoring points, with the need to increase stations, application of criteria for their spatialization and association with fluviometric stations, and, based on a greater assessment of water quality and quantity factors, support the framework proposals;

- difficulties in fluviometric stations in terms of scope, distribution and representativeness, which make it difficult to use adequate quantitative data;
- the presence of norms used for the framework that precedes the definitions of Brasil (2005) and Brasil (2008), with the need to reframe the water courses in the analyzed basins;

- the inexistence of charges for the use of water resources in the Paranapanema, Grande, Piancó-Piranhas-Açu and Verde Grande basins, making it difficult, due to lack of financial resources, to propose and maintain the framework for water courses;

- the lack of institutional coordination between water resource management bodies, Agency, States and municipalities, hindering the synergy between water management and land uses.

- In addition to the difficulties mentioned above, it was possible to identify some opportunities in proposing and implementing the framework, which can be summarized as:

- presence of the granting for the use of water resources in all the basins analyzed, which make use of the type of water body classified for the concession of punctual releases, in order to verify its capacity for necessary uses. However, while dealing with a strong point of the framework, it can impair its effectiveness, when considering only two quality parameters to assess the situation of the water course. It is necessary that other biological, physical and chemical elements, among those present in CONAMA Resolution no. 357/05, are also employed;

- the availability of charging for the use of water resources in the PCJ, São Francisco, Paraná, Paraíba do Sul and Doce basins, which is subsidizing the hiring of consultants to update basin plans and of reframing studies;

- presence of Delegation Basin Agencies in the basins of the PCJ and Paraíba do Sul rivers, which can act with a greater focus on the needs of the committees in relation to ANA, the Basin Agency of nine committees that have personalized characteristics and is responsible for water management of a large territorial areas of the country;

- the development of mechanisms for dialogue between the various institutions responsible directly and indirectly for the management of water quality, as listed by ANA in the Paraíba do Sul and Doce River basins. In this sense, it is necessary detailed analysis in respect of the methodologies used in these basins, in order to verify their effectiveness and applicability in other territories.

The problems presented do not have a simple solution and is expected that their identification and analysis being specific research objects in order to find the best strategies for better them. In addition, it was observed the need for a reflection on how the bodies responsible for water management share with other planning instances at different basin scales, such as municipalities and States, in order to promote the framework of water courses and, therefore, a progressive improvement in water quality. Participatory methodologies involving the government, users of water resources and members of civil society are essential to guarantee the agreed quality goals. 


\section{Contribution of authors:}

Souza, V.A.A.: Data curation, Formal analysis, Obtaining funding, Investigation, Project administration, Validation, Writing - original draft, Writing - review \& editing. Pizella, D.G.: Conceptualization, Methodology, Project administration, Supervision, Validation, Visualization, Writing — original draft, Writing review \& editing.

\section{References}

AGÊNCIA NACIONAL DE ÁGUAS (ANA). Cadernos de capacitação em recursos hídricos: implementação do enquadramento em bacias hidrográficas. Brasília: ANA, 2009.

AGÊNCIA NACIONAL DE ÁGUAS (ANA). Cadernos de capacitação em recursos hídricos: plano de recursos hídricos e enquadramento dos corpos de água. Brasília: ANA, 2013a.

AGÊNCIA NACIONAL DE ÁGUAS (ANA). Caderno de recursos hídricos: panorama do enquadramento dos corpos d'água do Brasil. Brasília: ANA, 2007.

AGÊNCIA NACIONAL DE ÁGUAS (ANA). Panorama da qualidade das águas superficiais do Brasil. Brasília: ANA, 2012.

AGÊNCIA NACIONAL DE ÁGUAS (ANA). Plano de recursos hídricos da bacia hidrográfica do Rio Verde Grande. Brasília: ANA, 2016a.

AGÊNCIA NACIONAL DE ÁGUAS (ANA). Plano de recursos hídricos do enquadramento dos corpos hídricos superficiais da bacia hidrográfica do Rio Paranaíba. Brasília: ANA, 2013b.

AGÊNCIA NACIONAL DE ÁGUAS (ANA). Plano de recursos hídricos do Rio Piancó-Piranhas-Açu: resumo executivo. Brasília: ANA, 2018.

AGÊNCIA NACIONAL DE ÁGUAS (ANA). Plano integrado de recursos hídricos da bacia hidrográfica do Rio Doce: relatório executivo. Brasília: ANA, 2013c.

AGÊNCIA NACIONAL DE ÁGUAS (ANA). Plano integrado de recursos hídricos da unidade de gestão de recursos hídricos Paranapanema. Brasília: ANA, 2016b.

AGÊNCIA NACIONAL DE ÁGUAS (ANA); COMITÊ DA BACIA HIDROGRÁFICA DO RIO GRANDE (CBH GRANDE). Plano Integrado de Recursos Hídricos da Bacia Hidrográfica do Rio Grande. Brasília: ANA, 2017.

BRAGA, B.P.F.; FLECHA, R.; PENA, D.S.; KELMAN, J. Pacto federativo e gestão de águas. Estudos Avançados, v. 22, n. 63, p. 17-42, 2008. https://doi. org/10.1590/S0103-40142008000200003

BRANDÃO, J.L.B.; MALTA, L.R.; MASINI, L.S.; STUART, L.C.; PORTO, M.F.A. Experiências nacional e internacional sobre o enquadramento dos cursos d'água. In: SIMPÓSIO DE RECURSOS HÍDRICOS DO SULSUDESTE, 1., 2006, Curitiba. Anais... ABRH, 2006. p. 1-20.

BRASIL. Resolução CONAMA nº 357, de 17 de março de 2005. Dispõe sobre a classificação dos corpos de água e diretrizes ambientais para o seu enquadramento, bem como estabelece as condições e padrões de lançamento de efluentes, e dá outras providências. Diário Oficial da União, Brasília, 18 mar. 2005.

BRASIL. Resolução do CNRH nº 91 , de 5 de novembro de 2008. Dispõe sobre procedimentos gerais para o enquadramento dos corpos de água superficiais e subterrâneos. Diário Oficial da União, Brasília, 2008.
BRITES, A.P.Z. Enquadramento dos corpos de água através de metas progressivas: probabilidade de ocorrência e custos de despoluição hídrica. $177 \mathrm{f}$. Tese (Doutorado em Engenharia Hidráulica e Sanitária) - Universidade de São Paulo, São Paulo, 2010.

COMITÊ DA BACIA HIDROGRÁFICA DO RIO SÃO FRANCISCO (CBHSF). Plano de Recursos Hídricos da Bacia Hidrográfica do Rio São Francisco. Alagoas: CBHSF, 2016.

COMITÊ DA BACIA HIDROGRÁFICA DO RIO PIANCÓ-PIRANHAS-AÇU (CBH DO RIO PIANCÓ-PIRANHAS-AÇU). O comitê - Trajetória, desafios e avanços do Comitê da Bacia Hidrográfica do Rio Piancó-Piranhas -Açu. Caicó, RN, 2019. Available at: $<$ http://www.cbhpiancopiranhasacu.org.br/portal/ocomite/>. Accessed: 18 Apr. 2019.

COMPANHIA DE DESENVOLVIMENTO DE RECURSOS HÍDRICOS E IRRIGAÇÃO (COHIDRO). Plano Integrado de Recursos Hídricos da Bacia Hidrográfica do Rio Paraíba do Sul e Planos de Ação de Recursos Hídricos das Bacias Afluentes. Resende: COHIDRO, 2014. v. 1.

CORRÊA, G.P.; JESUS, J.A.O.; PERSECHINI, I.; PETELINKAR, L.C.; TOZZI, B.M.; TOZZI, R.F.; GALLEGO, C.E.C.; BITTENCOURT, A.G.; PEREIRA, C.A.A.O. O processo do enquadramento dos corpos hídricos superficiais: estudo de caso da bacia do Rio Paranaíba, Brasil. In: SIMPÓSIO BRASILEIRO DE RECURSOS HÍDRICOS, 20., 2013, Curitiba. Anais... ABRH, 2013. 8 p.

CUNHA, D.G.F.; CALIJURI, M.C.; LAMPARELLI, M.C.; MENEGON JR., N. Resolução CONAMA n 357/2005: análise espacial e temporal de não conformidades em rios e reservatórios do estado de São Paulo de acordo com seus enquadramentos (2005-2009). Engenharia Sanitária e Ambiental, v. 18, n. 2, p. 159-168, 2013. https://doi.org/10.1590/S1413-41522013000200008

DINIZ, L.T.; YAZAKI, L.F.O.; JUNIOR, J.M.M.; PORTO, M.F.A. O enquadramento de cursos d'água na legislação brasileira. In: SIMPÓSIO DE RECURSOS HÍDRICOS DO SUL-SUDESTE, 1., 2006, Curitiba. Anais... ABRH, 2006. p. 1-19.

ECOPLAN. Plano Integrado de Recursos Hídricos da Bacia Hidrográfica do Rio Doce. Brasília: ECOPLAN, 2010. v. 1.

FOLETO, E.M. O Contexto dos Instrumentos de Gerenciamento dos Recursos Hídricos no Brasil. Geoambiente, n. 30, p. 39-59, 2018. https://doi. org/10.5216/revgeoamb.v0i30.52823

GIL, A.C. Como elaborar projetos de pesquisa. 4. ed. São Paulo: Atlas, 2002. 176 .

OLIVEIRA-ANDREOLI, E.Z.; SILVA, F.L.; LÓPEZ, F.M.A.; MACHADO, R.; TEODORO, C.C.; BIANCHINI JÚNIOR, I.; CUNHA-SANTINO, M.B.; FUSHITA, A.T.; CRESTANA, S. Importância do planejamento regional para a manutenção dos usos múltiplos da água em bacias hidrográficas. Revista Brasileira de Ciências Ambientais, n. 5, p. 16-27, 2019. 
PIZELLA, D.G. A relação entre Planos Diretores Municipais e Planos de Bacias Hidrográficas na gestão hídrica. Ambiente \& Água, v. 10, n. 3, p. 635-645, 2015. http://dx.doi.org/10.4136/ambi-agua.1394

PIZELLA, D.G.; SOUZA, M.P. Análise da sustentabilidade ambiental do sistema de classificação das águas doces superficiais brasileiras. Engenharia Sanitária e Ambiental, v. 12, n. 2, p. 139-148, 2007. http://dx.doi.org/10.1590/ S1413-41522007000200005

PORTO, M.F.A.; PORTO, R.L. Gestão de bacias hidrográficas. Estudos Avançados, v. 22, n. 63, p. 43-60, 2008.

PROFILL. Complementação e Finalização do Plano Integrado de Recursos Hídricos da Bacia Hidrográfica do Rio Paraíba do Sul: PIRH-PS e Elaboração dos Planos de Recursos Hídricos das Bacias Hidrográficas Afluentes. Resende: PROFILL, 2018. v. 1.

PROFILL; RHAMA. Primeira Revisão do Plano das Bacias Hidrográficas dos Rios Piracicaba, Capivari e Jundiaí 2010 a 2020. Piracicaba, 2018a. v. 1.
PROFILL; RHAMA. Primeira Revisão do Plano das Bacias Hidrográficas dos Rios Piracicaba, Capivari e Jundiaí 2010 a 2020. Piracicaba, 2018b. v. 2.

RODORFF, V.; SIEGMUND-SCHULTZE; KÖPPEL, J.; GOMES, E.T.A.

Governança da Bacia Hidrográfica do Rio São Francisco: desafios de escala sob olhares inter e transdisciplinares. Revista Brasileira de Ciências Ambientais, $\mathrm{n}$. 36, p. 19-44, 2015. https://doi.org/10.5327/Z2176-947820151003

SILVA, M.T.L. Aplicação do Índice de conformidade ao enquadramento (ICE) de cursos d’água. 2017. 201 f. Dissertação (Mestrado) - Curso de Programa de Pósgraduação em Saneamento, Meio Ambiente e Recursos Hídricos, Engenharia Sanitária, Universidade Federal de Minas Gerais, Belo Horizonte, MG, 2017. Available at: $<$ https://ptarh.unb.br/dissertacoes/proposicao-de-suportemetodologico-para-enquadramento-de-cursos-de-agua/>. Accessed: 15 Aug. 2019.

YASSUDA, E.R. Gestão de Recursos Hídricos: Fundamentos e Aspectos Institucionais. Rev. Adm. púb, v. 27, n.2, p.5-18, 1993. 


\section{APPENDIX 1 - Model of the questionnaires sent to Interstate's Basin Committees and the National Water Agency.}

1. Select your role in the National Water Resources Management System (SINGREH):

- Member of BC Piracicaba, Capivari and Jundiaí

- Member of BC Paraíba do Sul

- Member of BC Paranaíba

- Member of BC Paranapanema

- Member of BC Piancó-Piranhas-Açu

- Member of BC Rio Grande

- Member of BC São Francisco

- Member of BC Verde Grande

2. Are you part of a Technical Chamber or Technical Group for framing matters?

- Yes

- No

Which one?

3. What is the quality of surface freshwater in the hydrographic ba$\sin$ ?

- Great

- Good

- Regular

- Bad

- Unsatisfactory

- Very unsatisfactory

- I have no knowledge

4. What is your opinion on the availability of surface freshwaters in the hydrographic basin?

- Great

- Good

- Regular

- Bad

- Unsatisfactory

- Very unsatisfactory

- I have no knowledge

5. Does the hydrographic basin have a Water Resources Plan?

- Yes

- No

6. How is the framework addressed in the Water Resources Plan?

- It is not considered

- There is a framework proposal

- There are only guidelines to elaborate the framework (standards, priority areas, among others)

Considerations:
7. What is the current status of the framework in the basin?

- Nonexistent. Water curses automatically in Class 2

- Pending in the committee

- Approved by the committee

- Submitted to the National Water Resources Council for deliberation

- In the process of adjustments requested by the National Water Resources Council

- Approved by the National Water Council

Considerations:

8. What items are considered in the framework proposal below? (Check all that apply)

- Preponderant uses

- Uses intended by society

- Social participation (local community)

9. What parameters were considered for the framing of water bodies in the watershed? (Check all that apply)

- $\mathrm{DBO}_{5,20}$

- Dissolved oxygen

- Total phosphorus

- Nitrate

- Nitrite

- Total ammoniacal nitrogen

- I have no knowledge

If there are others, quote:

10. Was the instrument granting for the use of water resources implemented in the hydrographic basin?

- Yes

- No

- I have no knowledge

Considerations:

11. Is the water resource class considered in the grant criteria?

- Yes

- No

- I have no knowledge

Considerations:

12. What are the water standards criteria considered for granting?

- $\mathrm{DBO}_{5,20}$

- Dissolved oxygen

- Total phosphorus

- Nitrate

- Nitrite 
- Total ammoniacal nitrogen

- I have no knowledge

If there are others, quote:

13. Has the instrument charging for the use of water resources been implemented in the hydrographic basin?

- Yes

- No

- I have no knowledge

Considerations:

14. Judge the following statement: The financial resources arising from the charging in the hydrographic basin are adequate for the elaboration of the proposed framework for water courses or for their monitoring, if already implemented.

- I agree

- I strongly agree

- I disagree

- I strongly disagree

- I have no knowledge

Considerations:

15. Judge the following statement: The revision of the charge for the use of water resources would be a factor that would corroborate for the realization of the framework according to Resolution CNRH no. 91/2008 or its follow-up, if already implemented.

- I agree

- I strongly agree

- I disagree

- I strongly disagree

- I have no knowledge

Considerations:

16. Judge the following statement: The implementation of charging for the use of water resources would be a factor that would corroborate for the elaboration of studies on the framing of superficial water courses or their monitoring, if already implemented.

- I agree

- I strongly agree

- I disagree

- I strongly disagree

- I have no knowledge

Considerations:

17. Judge the following statement: The quantity and distribution of surface water quality monitoring points in the watershed are satisfactory.

- I agree
- I strongly agree

- I disagree

- I strongly disagree

- I have no knowledge

Considerations:

18. In case of disagreement in the previous question, is an unsatisfactory quantity and the distribution of monitoring points a factor that makes it difficult to framework these water courses?

- I agree

- I strongly agree

- I disagree

- I strongly disagree

- I have no knowledge

Considerations:

19. What are the main polluting sources of surface freshwater present in the watershed?

- Industries

- Sanitary sewage

- Agriculture

- Livestok

- Urban areas

Anothers:

20. Judge the following statement: The quantity and distribution of fluviometric monitoring points for surface waters in the watershed are satisfactory.

- I agree

- I strongly agree

- I disagree

- I strongly disagree

- I have no knowledge

Considerations:

21. What would be the appropriate amount of water and fluviometric quality monitoring points in the hydrographic basin (following on the proposal and implementation of the framework)?.

22. Judge the following statement: ANA's technical staff is sufficient and able to prepare the proposed framework (or follow-up, if already implemented) for water courses in accordance with the precepts of Resolution CNRH no. 91/2008.

- I agree

- I strongly agree

- I disagree

- I strongly disagree

- I have no knowledge

Considerations: 
23. Judge the following statement: The wide extension (area) of the hydrographic basin is a factor that makes it difficult to execute the framework or its monitoring, considering the specificities of each water course in terms of its intended uses, predominant uses and participation of society, as advocated by CNRH Resolution no. 91/2008.

- I agree

- I strongly agree

- I disagree

- I strongly disagree

- I have no knowledge

Considerations:
24. Judge the following statement: There is institutional articulation between the Basin Committee and the States, as well as the municipalities that act in ordering land use in their jurisdictions, in the discussion about the framework.

- I agree

- I strongly agree

- I disagree

- I strongly disagree

- I have no knowledge

Considerations: 